\title{
Lost Immune Markers for Major Affective Disorders: Could They Help Screen Airline Pilots?
}

\author{
Allen D. Allen ${ }^{1,2,3^{*}}$ \\ ${ }^{1}$ Center for Viral Diseases, Northridge, CA, USA \\ ${ }^{2}$ Olive View-UCLA Medical Center, Sylmar, CA, USA \\ ${ }^{3}$ CytoDyn, Inc., Santa Fe, NM, USA \\ Email: allend.allen@yahoo.com
}

Received 7 April 2015; accepted 18 April 2015; published 22 April 2015

Copyright (C) 2015 by author and Scientific Research Publishing Inc.

This work is licensed under the Creative Commons Attribution International License (CC BY). http://creativecommons.org/licenses/by/4.0/

(c) (i) Open Access

\section{Abstract}

In the 1980s it was discovered that quantitative IgG titers for antibodies directed against the human-obligate DNA viruses were reliably and reproducibly correlated negatively with mood in individuals with major affective disorders. This knowledge was lost to confirmation bias and uncontrolled studies that only looked at Epstein-Barr virus antibodies. The latter led to a long American fad of misdiagnosing major affective disorders as a "chronic Epstein-Barr virus syndrome." This misdiagnosis even became part of the American popular culture during the 1980s. In light of fatal airline crashes intentionally caused by pilots, the antiviral IgG titers should be revisited as a means of screening pilots for current dysphoria or mania/hypomania due to major affective disorders.

\section{Keywords}

Aviation Disasters, Suicide with Mass Murder, Major Affective Disorders, Chronic Epstein-Barr Virus Syndrome, Quantitative IgG Titers for Human-Obligate DNA Virus Antibodies

\section{Introduction}

As is well known, there have been several fatal crashes of commercial passenger jets that are known or believed to have been intentionally caused by a pilot. According to widespread reports in the news media, the most recent example as of this writing is the fatal crash of Germanwings flight 9525 from Barcelona, Spain to Düsseldorf,

${ }^{*}$ Retired. 
Germany on March 24, 2015 [1]-[4]. All 150 people on board were killed. Investigators quickly determined that this crash occurred after the 27-year-old copilot, Andreas Lubitz, locked the captain out of the cockpit and flew the plane at high speeds into the French alps. At the time Mr. Lubitz was hired, Germanwings, which became a wholly-owned subsidiary of Lufthansa in 2009, knew that he had a history of major depression with suicidal ideation. This generated much public discussion and debate about how to prevent such disasters.

Understandably, the families of the victims of flight 9525 questioned whether a person with a known history of major depression and suicidal ideation should be licensed as a commercial airline pilot. The expert opinion, however, is that such a history should not, in and of itself, disqualify an individual from being a pilot. For one thing, people can have a major depressive episode that resolves and is not recurring. Likewise, many individuals with major depression can be successfully treated. Given the high lifetime morbidity risk for major depression [5] and the current shortage of pilots [6], the banning of individuals based on a mere history of major depression seems excessive.

Commercial airline pilots are given physical examinations annually or semiannually, depending upon their age. These examinations do not include psychometric testing or thorough evaluation of a pilot's mental health by a psychiatrist. Rudimentary mental health questions are asked by flight surgeons but flight surgeons are usually not trained in psychiatry. This screening seems inadequate at best. Furthermore, the current practice of self-reporting has several limitations. Pilots may mask mood disorders and deny diagnoses and treatment recommendations for fear of harming their careers. Worse yet, they may do so precisely because they plan on committing mass murder and suicide, as was apparently the case with Mr. Lubitz. An obvious answer would be a blood test that could screen for current dysphoria or mania/hypomania associated with major affective disorders. A blood panel that could accomplish this by the quantitative measurement of certain antiviral IgG titers was discovered in the 1980s. Unfortunately, this knowledge was lost to confirmation bias and uncontrolled studies that led to a long American fad of misdiagnosing major affective disorders as a "chronic Epstein-Barr virus syndrome."

\section{A Brief History of the Chronic Epstein-Barr Virus Fad}

In the mid-1980s, researchers at the US National Institutes of Health [7], along with others [8] [9], reported finding elevated IgG titers directed against the Epstein-Barr virus (EBV) in the circulating blood of adults with a widespread, persistent, unexplained illness. This author and colleagues [10] [11], followed by others [12] [13], replicated these findings but recognized the "persistent unexplained illness" as major affective disorder. Delisi, et al. at the US National Institute of Mental Health, replicated our findings but recommended that this phenomenon be ignored so as not to "confuse" psychiatrists.

Delisi, et al. had a point. The original research that associated EBV antibodies with a persistent, unexplained illness had created a fad among America's primary-care physicians. They began misdiagnosing major affective disorders as a syndrome associated with chronic Epstein-Barr virus infection. This fad lasted for years and even made its way into the lexicon of America's popular culture during the 1980s. Unfortunately, treating the patients in question for an EBV infection, e.g., by prescribing antiviral drugs such as acyclovir, provided no benefit to the patients. On the other hand, this author and colleagues had considerable success in treating them with antidepressants [14]. In other words, Delisis, et al. were correct in recommending that the elevated IgG titers directed against EBV not be deemed an etiological factor used to modify the treatment of major affective disorders.

It occurred to this author that there was only one alternative hypothesis: the elevated IgG titers must reflect dysregulation of humoral immunity in individuals suffering from major affective disorders. Indeed, by looking at multiple IgG titers in the peripheral blood from a large psychiatric population, I found that IgG titers directed against many or all of the human-obligate DNA viruses were reproducibly and reliably correlated negatively with mood. Recall that these viruses include cytomegalovirus, varicella-zoster, and herpes simplex serotypes 1 and 2 along with EBV. By "correlated negatively with mood" I mean that in bipolar patients, the titers were elevated in depressive phase but attenuated, or even absent, in manic or hypomanic phase. Many of the bipolar patients we saw in our clinic had become traumatized and confused as a result [15]. Having presented to their primary-care physician in depressive phase, they were told that they had chronic Epstein-Barr virus syndrome. During a follow-up visit in hypomanic phase, they were told that the reason they felt so much better is that the laboratory had made a mistake and they didn’t have chronic Epstein-Barr virus syndrome. When they returned 
again with significant morbidity in depressive phase, they were told that the first time the laboratory had made a mistake but this time they did have chronic Epstein-Barr virus syndrome. Is it any wonder that these patients had lost confidence in their primary-care physicians?

These findings were met with great resistance due to multiple examples of confirmation bias. For one thing, many researchers and clinicians had staked their reputations on the notion of a chronic Epstein-Barr virus syndrome. Moreover, which of us hasn't been taught that antiviral antibodies occur in response to a viral infection and then persist afterwards? The finding that IgG antibodies to ubiquitous DNA viruses could come and go with the mood of the patient was so contrary to acquired medical bias that this finding was ignored despite being reliably reproducible. My only opportunity to report it in the literature was in the context of a study on chronic fatigue syndrome, which gradually replaced the chronic Epstein-Barr virus fad. This study was on adult woman who had become persistently and severely morbid following immunization against rubella in order to maintain herd immunity to prevent congenital deafness. As shown in Figure 1, these women had the typical elevation of IgG titers directed against DNA viruses with the addition of elevated titers to rubella [16].

To summarize these findings, dozens of independent researchers, including those working for the US National Institutes of Health and Institute of Mental Health, as well as those working for major universities [7]-[16], have found in numerous studies that IgG antibodies directed against the human-obligate DNA viruses, such as Epstein-Barr virus, are elevated in individuals currently suffering from major depression. What this means pathophysiologically is not understood, although it is clear from clinical practice that treating such patients with antivirals rather than anti-depressants is ineffective [14] [15]. The point here is that when independent reasearchers conduct the same experiment dozens of times and it always turns out the same way, one should accept those results if he or she is to be considered a scientist. The value of a blood test that screens for major affective disorders is that it could provide an acceptable way of improving the screening of airline pilots. Such screening would not encourage pilots to mask or deny symptoms, nor would it dissuade pilots from seeking treatment for fear of harming their careers.

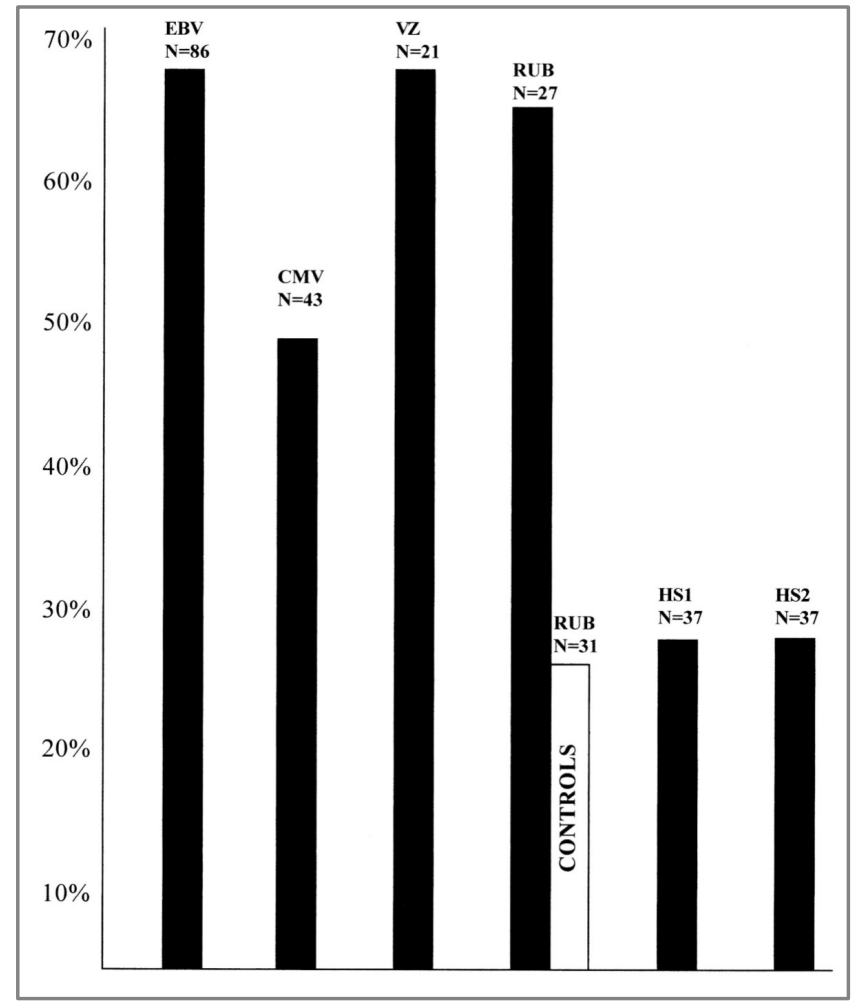

Figure 1. Adapted from [16]. Percentage of patients with elevated IgG titers in a cohort with "chronic fatigue syndrome," including adult women who became persistently and severely morbid following immunization with RA-27/3 rubella vaccine. Legend: EBV = Epstein-Barr virus; CMV = cytomegalovirus; VZ = varicella zoster; RUB = rubella (controls are women who were immunized without sequelae); HS1 = herpes simplex serotype 1; HS2 = herpes simplex serotype 2. 


\section{Conclusion}

In light of the need to screen commercial airline pilots for major affective disorders, the use of quantitative IgG titers directed against the human-obligate DNA viruses should be revisited. Needless to say, this blood panel should only be used for screening purposes in order to identify current dysphoria or mania/hypomania due to major affective disorders. A positive outcome would result in a more comprehensive workup of the pilot's mental health by a qualified mental-health professional before any decisions were made. After all, individuals who commit suicide due to depression per se kill themselves in order to escape the morbidity of depression. On the other hand, pilots who commit mass murder while killing themselves are likely to have a concomitant personality disorder. As is well known among psychotherapists, patients with borderline personality disorder sometimes commit suicide in order to punish someone, such as the therapist, an employer, a parent or a spouse. Likewise, the post-mortem infamy that attaches to pilots who perpetrate airline disasters may suggest a narcissistic personality disorder.

\section{References}

[1] http://www.chicagotribune.com/news/nationworld/chi-germanwings-crash-co-pilot-20150405-story.html

[2] http://www.cbsnews.com/news/search-resumes-at-germanwings-flight-9525-crash-site/

[3] http://www.cnn.com/2015/03/24/europe/france-plane-crash/index.html

[4] http://www.nytimes.com/video/world/europe/100000003607972/prosecutor-on-co-pilots-search-history.html

[5] Kessler, R.C., McGonagle, K.A., Shanyang, Z., Nelson, C.B., Hughes, M., Eshleman, S., Wiitchen, H.-U. and Kendler, K.S. (1994) Lifetime and 12-Month Prevelance of DSM-III-R Psychiatric Disorders in the United States: Results from the National Comorbidity Survey. Archives of General Psychiatry, 51, 8-19. http://dx.doi.org/10.1001/archpsyc.1994.03950010008002

[6] http://www.newsmax.com/US/pilot-shortage-rules-regulations/2014/02/04/id/550729/

[7] Straus, S.E., Tosato, G., Armstrong, G., et al. (1985) Persisting Illness and Fatigue in Adults with Evidence of EpsteinBarr Virus Infection. Annals of Internal Medicine, 102, 102-107. http://dx.doi.org/10.7326/0003-4819-102-1-7

[8] Jones, J.F., Ray, C.G., Minnich, L.L., et al. (1985) Evidence for Active Epstein-Barr Virus Infection in Patients with Persistent, Unexplained Illnesses: Elevated Anti-Early Antigen Antibodies. Annals of Internal Medicine, 102, 1-7. http://dx.doi.org/10.7326/0003-4819-102-1-

[9] Tobi, M., Morag, A., Ravid, Z., et al. (1982) Prolonged Atypical Illness Associated with Serological Evidence of Persistent Epstein-Barr Virus Infection. Lancet, 1, 61-64. http://dx.doi.org/10.1016/S0140-6736(82)90210-0

[10] Allen, A.D. and Tilkian, S.M. (1986) Depression Correlated with Cellular Immunity in Systemic Immunodeficient Epstein-Barr Virus Syndrome (SIDES). Journal of Clinical Psychiatry, 47, 133-135.

[11] Pitts Jr., F.N., Allen, R.E. and Allen, A.D. (1989) Antibodies to the Early Antigen of the Epstein Barr Virus in Relation to Major Depression. In: Miller, A.H., Ed., Depressive Disorders and Immunity, American Psychiatric Press, Washington DC.

[12] Dubner, N.P., Durant, D.L. and Creech, F.R. (1987) Epstein-Barr Antibodies in Three Psychiatric Syndromes. Psychiatric Hospital, 20, 167-170.

[13] Delisi, L.E., Nurnberger, J.L., Goldin, L.R., et al. (1986) Epstein-Barr Virus and Depression. Archives of General Psychiatry, 43, 816-817. http://dx.doi.org/10.1001/archpsyc.1986.01800080101016

[14] Allen, A.D., Pitts Jr., F.N. and Allen, R.E. (1987) Lake Tahoe Mystery Disease. Science, 235, 623. http://dx.doi.org/10.1126/science.235.4789.623e

[15] Allen, A.D., Fudenberg, H.H. and Allen, R.E. (1987) Affective Disorder and Viral Infection. American Journal of Psychiatry, 144, 1374.

[16] Allen, A.D. (1988) Is RA27/3 Rubella Immunization a Cause of Chronic Fatigue? Medical Hypotheses, 27, $217-220$. http://dx.doi.org/10.1016/0306-9877(88)90146-6 